\title{
Prevalence and causes of low vision and blindness worldwide
}

\section{AO Oduntan*}

Department of Optometry, University of Limpopo, Private Bag X1106, Sovenga, 0727 South Africa

<alabio@ul.ac.za>

\begin{abstract}
A recent review of the causes and prevalence of low vision and blindness world wide is lacking. Such review is important for highlighting the causes and prevalence of visual impairment in the different parts of the world. Also, it is important in providing information on the types and magnitude of eye care programs needed in different parts of the world. In this article, the causes and prevalence of low vision and blindness in different parts of the world are reviewed and the socio-economic and psychological implications are briefly discussed. The review is based on an extensive review of the literature using computer data bases combined with review of available national, regional and international journals. Low vision and blindness are more prevalent in the developing countries than in the developed ones. Generally, the causes and prevalence of the conditions vary widely in different parts of the world and even within the same country. World wide, cataract is the most common cause of blindness and low vision among adults and elderly. Infectious diseases such as trachoma and onchocerciasis resulting in low vision and blindness are peculiar to Africa, Asia and South America. Hereditary and congenital conditions are the most common causes of low vision and blindness among children worldwide.
\end{abstract}

Keywords: Visual impairment, blindness, low vision, partial sight, prevalence, cataract, childhood blindness.

\section{Introduction}

There are many low vision and blind people worldwide, and there is a considerable amount of data available on the prevalence of low vision and blindness in many parts of the world. The data, however, vary significantly from one continent to another. In 1995, the World Health Organization (WHO) Task Force on data on blindness estimated that there were 37.1 million blind people worldwide, indicating a global prevalence of 0.7 percent ${ }^{1}$. According to that report, the prevalence values range from $0.3 \%$ in the developed countries to $1.4 \%$ in Sub-Saharan African countries. The prevalence of visual impairment is expected to be higher in the developing countries due to the low level of health care services in many of the countries. It has subsequently been reported that 110 million people have severely impaired vision, hence are at great risk of becoming blind ${ }^{2}$. More recently, following a review of available data, Watkins ${ }^{3}$ estimated that there were about 40 million people $(0.7 \%)$ who are blind worldwide and predicted an annual increase of about two million. In both developing and developed countries, the prevalence of low vision and blindness increases with age, particularly among people over 60 years of age. This is due to age-related eye diseases such as cataract, macular degeneration et cetera, which have high prevalence among this age group. A review of available data on prevalence of low vision and blindness in various regions of the world is presented below.

\section{Africa}

It is generally known that Africa has a high rate 
of blindness. It has been estimated that approximately $1 \%$ of Africa's population is blind ${ }^{4}$ and a higher prevalence has been estimated for SubSaharan Africa ${ }^{1}$. The most common causes of low vision and blindness among adults are cataract, corneal and retinal diseases. About half of the blindness is due to cataract alone ${ }^{5,6}$. Women accounted for approximately $60 \%$ of the blind; an age-adjusted prevalence of blindness in women was 1.39 times higher than in males ${ }^{5,6}$. A national blindness prevalence of $0.7 \%$ was reported for Ghana based on hospital data ${ }^{7}$. A subsequent population-based survey ${ }^{8}$ on the prevalence of major blinding disorder in the Wenchi district in central Ghana estimated the prevalence of blindness among those 30 years and older to be $1.7 \%$, and additionally, the prevalence of low vision was $2 \%$. That study showed that cataract $(62.5 \%)$ was the most common cause of blindness in individuals aged 30 years and older. Other common causes of blindness identified in that study were onchocerciasis $(12.5 \%)$, non-trachomatous corneal opacity $(8.2 \%)$, and refractive error (4.2\%). Blindness and low vision in the extreme Northern Province of Cameroon has been attributed mainly to cataract ${ }^{9}$. A survey ${ }^{10}$ in South Western Nigeria showed blindness rate of $0.9 \%$, and cataract, $(48.1 \%)$ and onchocerciasis $(14.8 \%)$ were the most common causes of blindness. Another survey ${ }^{11}$ in Eastern Nigeria also identified cataract $(70.6 \%)$, glaucoma $(17.65 \%)$ and macular degeneration $(5.9 \%)$ as the most common (54\%) causes of blindness. In the rural districts of Segou in Mali, cataract was reported to be the most common cause of visual loss and was most prevalent among those 50 years of age and older ${ }^{12}$. Other causes in that study were trachoma and glaucoma. In the Central African Republic, cataract (51\%) was found to be the main cause of blindness, followed by glaucoma $(12.7 \%)$ and onchocerciasis $(8.1 \%)^{13}$.

A survey ${ }^{14}$ of ocular status of Kenyan rural communities showed that $0.7 \%$ of the population sample was blind and another $2.6 \%$ were partially sighted. Cataract, (36\% of all blindness) was the major cause of blindness and was responsible for $39 \%$ of all low vision cases. Other common conditions in that rural Kenya study were non-tracho- matous infections and trachoma, which occurred in $0.4 \%$ and $0.3 \%$ of the population respectively. In another study ${ }^{15}$ among the Turkana tribe in the North West of Kenya, the major causes of blindness among those below 35 years of age were corneal diseases from xerophthalmia and trachoma. Among those over 45 years, cataract was the main cause of blindness. In a population based survey ${ }^{16}$ in the Hammer tribe of Ethiopia, blindness occurred in $1.9 \%$ of the population. Among those aged 40 years and over, $1 \%$ of the men and 13\% of the women were blind. Women and men with low vision or blindness comprised $30 \%$ in that age stratum. The survey identified cataract as the major cause of blindness. A similar survey in the Jimma Zone of Ethiopia ${ }^{17}$, found cataract (56.8\%), refractive error $(28.8 \%)$, and corneal opacity $(12.8 \%)$ to be major causes of low vision. Also, cataract and aphakia (52.4\%), corneal opacity and phthisis bulbi $(25.4 \%)$ and glaucoma (9.5\%) featured significantly as major causes of blindness.

In South Africa, a population-based study showed that cataract and glaucoma were the major causes of blindness in the rural parts of KwaZulu Natal Province ${ }^{18}$. A similar study in the Northern part of South Africa found the prevalence of blindness to be $0.5 \%$ and women had higher prevalence than men $^{19}$. Cataract (55\%), corneal scarring due to trachoma (10\%), uncorrected aphakia $(9 \%)$ and open angle glaucoma $(6 \%)$ were found to be major causes of blindness ${ }^{19}$. In 1995, the national population of South Africa was estimated at about 41 million out of which about 131000 were estimated to be partially sighted and 262000 estimated to be blind $^{20}$. The total number of the visually impaired, therefore, was about 400000 . The prevalence of low vision in South Africa according to these figures was reported to be $0.32 \%$ and that of blindness was 0.64 per cent $^{20}$. A more recent study in the central region of the Limpopo Province of South Africa $^{21}$, reported prevalence of low vision, monocular blindness and binocular blindness of $2.43 \%$, $1.77 \%$ and $0.73 \%$ respectively and the main causes of low vision were cataract, corneal opacities and glaucoma. Other causes were hypertensive retinopathy, diabetic retinopathy, and trauma. The main causes of monocular blindness were cataract, 
trauma and infections, while the major causes of binocular blindness were cataract, glaucoma, corneal opacities, and trauma.

Corneal diseases are common in many parts of Africa and are mainly due to malnutrition or infections such as onchocerciasis and trachoma. Onchocerciasis is a major ocular health problem in equatorial West Africa. In Liberia ${ }^{22}$, onchocerciasis was reported as the cause of all blindness, and one-third of low vision. Over half of the visual impairment caused by onchocerciasis was due to posterior segment diseases such as chorioretinal disorder and retinal pigment epithelium atrophy.

The above review shows that cataract is a major cause of blindness in all parts of Africa. Fortunately, most of the blindness due to cataract can be reversed following cataract surgery with intra-ocular implant or contact or ophthalmic lenses. Unfortunately, however, the scarcity of ophthalmologists is a major problem affecting eye care services in many parts of Africa. Also, poor distribution of optometrists resulting in scarcity of optometrists in the rural areas could be a contributing factor as this will affect referral. Infectious diseases and malnutrition are also considered to be a common cause of blindness, especially in the rural areas of Africa.

\section{Americas and Canada}

In the Baltimore eye survey, the rates of visual loss with functional consequences was found to range from $0.74 \%$ among the white population aged $40-49$ years to $26 \%$ among blacks 80 years and older $^{23}$. In a study in East Baltimore ${ }^{24}$, which included those that are 40 years and older, $22 \%$ of blindness was due to senile cataract and $15 \%$ was due to age-related macular degeneration and $13 \%$ of blindness cases was due to glaucoma. In Salisbury (Maryland) eye evaluation study ${ }^{25}$, macular degeneration (1.2\%) was more common among the whites compared to $0.5 \%$ among the blacks, whereas, cataract $2.7 \%$ vs $1.1 \%$, glaucoma $0.9 \%$ vs $0.1 \%$ and diabetic retinopathy (1.2 vs $0.2 \%$ ) were more common among the African Americans. In a review presented by Munoz and West $^{26}$, cataract, glaucoma and diabetic retinopathy were the common causes of blindness among those
40 years and older in Chile, Brazil and Peru. Agerelated macular degeneration has been documented as a leading cause of blindness among elderly patients in Canada, accounting for 40 to $50 \%$ of new cases of blindness ${ }^{27}$.

\section{East Mediterranean and Asia Pacific region}

The prevalence of low vision and blindness in Asia is relatively high and cataract has been identified as a major cause. It has been estimated that the prevalence of blindness in India ${ }^{6}$ is $1 \%$ and cataract, ( $80 \%$ of blindness cases) has been found to be a major cause of blindness ${ }^{28,29}$. It was further estimated that nearly 4 million people are blinded by cataract in India each year ${ }^{29}$. In Saudi Arabia, the prevalence of low vision and blindness among the general population has been reported to be 7.8 $\%$ and $1.5 \%$ respectively ${ }^{30}$ and cataract $(52.8 \%)$ was the leading causes of blindness, affecting more females than males. Other common causes were trachoma (10.5\%), non-trachomatous corneal scars $(8.8 \%)$, uncorrected refractive error $(8.8 \%)$, and congenital anomalies (5.1\%). In Bangladesh, cataract and refractive error have been reported as the main causes of blindness ${ }^{31}$. In Mongolia ${ }^{32}$, a survey of those aged 40 years and older revealed a prevalence of $1.5 \%$ for blindness and $0.64 \%$, for low vision, which were equivalent to a national estimate of $1.4 \%$ and $7.7 \%$ respectively. It was established that cataract $(35 \%)$ and glaucoma (35\%) were the main causes of blindness in that country. In Lebanon, the prevalence of low vision was 3.9\% and blindness $0.6 \%$ and cataract and uncorrected high refractive errors were found to be common causes of visual impairment ${ }^{33}$. Prevalence of low vision and blindness in Teharan, Iran was reported to be $1.11 \%$ and $0.39 \%$ and the major causes were cataract $(36 \%)$, macular degeneration $(20 \%)$ and amblyopia $(10.7 \%)^{34}$. The prevalence of blindness in $\mathrm{Nepal}^{35}$ has been estimated to be $0.84 \%$. In a survey $^{36}$ of patients who attended the low vision clinic of the Hong Kong Society for the Blind, cataract $(27.4 \%)$ was found to be the main cause of visual impairment. Myopic degeneration (9\%) and age-related macular degeneration (8.8\%) were also found to be important causes of low vision.

A population-based survey ${ }^{37}$ of visual impair- 
ment and blindness in a sub-urban area of Hong Kong also found that cataract and refractive errors were the main causes of visual impairment and blindness among people 60 years and older. Others were myopic degeneration $(9.0 \%)$ and age related macular degeneration (8.8\%). A national sample survey of blindness and low vision in $\mathrm{China}^{38}$ indicated the prevalence of blindness and low vision was 0.43 percent and the major causes of the conditions were cataract $(41.06 \%)$, corneal diseases $(15.38 \%)$, trachoma (10.87\%), and glaucoma $(8.8 \%)$. In Malaysia ${ }^{39}$, among the general population, the most common causes of low vision were congenital structural defects, nystagmus, retinitis pigmentosa, and macular dystrophy. Among those 60 years and older, however, macular degeneration, diabetic retinopathy and glaucoma were the most common causes of low vision. Retinitis pigmentosa $(21.5 \%)$ was found to be the main cause of low vision in the 30-59 age groups.

\section{Europe}

The prevalence of blindness in the European Economic Community (EEC) has been reported ${ }^{40}$ to be $0.2 \%$. Using the data collected from blindness registration certificates, Giltrow-Tyler ${ }^{41}$ found that the major causes of blindness in England among adults 65 years and older were degenerative macula, posterior pole condition $(43.2 \%)$, glaucoma (9.1\%) senile cataract $(6.7 \%)$ and diabetic retinopathy (5.8\%). Among the 16-64 years age groups, the major causes of blindness were diabetic retinopathy $(19.7 \%)$, hereditary retinal dystrophies (10.8\%), and optic atrophy (10.4\%). A retrospective review ${ }^{42}$ of similar data for the period 1980-1985 in the Bradford Metropolitan district showed that age-related macular degeneration was the most important cause of visual handicap, accounting for $43.9 \%$ of all registrations. Other common causes were glaucoma $(16.2 \%)$, diabetic retinopathy $(6.3 \%)$, myopic degeneration $(6.1 \%)$, optic atrophy $(4.4 \%)$, cerebrovascular diseases (3.8\%), cataract (3.6\%), and retinal vascular occlusive disease $(3.2 \%)$. The ratio of female to male registration was found to be 1.8:1. A study of the causes of blindness in the adult population of the republic of Ireland reported macular degeneration
$(16 \%)$, glaucoma $(16 \%)$ and cataract $11 \%$ as the main causes of low vision and blindness ${ }^{43}$.

Among the elderly population registered as blind in Denmark, 71\% had age-related macular degeneration ${ }^{44}$. A population-based survey on middle aged and elderly population in Casteldaccia, Sicily ${ }^{45}$ showed that the prevalence of low vision and blindness were $1.22 \%$ and $0.47 \%$ respectively among the middle aged and elderly populations and the major cause of blindness was cataract, followed by amblyopia. A blindness and low vision survey ${ }^{40}$ in South East Turkey reported a prevalence of low vision of $1.5 \%$ and that of blindness was 0.45 percent. Compared with the blindness prevalence of $0.2 \%$ in the European Economic Community, the age standardized prevalence of blindness in South East Turkey was eight times as high and low vision and blindness were due to cataract (50\%), corneal opacity $(15 \%)$, and glaucoma $(12 \%)^{40}$.

\section{Oceania}

A study of visual impairment and eye diseases in elderly institutionalized Australians found age-related macular degeneration $(44 \%)$ to be the main cause of low vision and blindness ${ }^{46}$. A survey among the Australian elderly population, 50 years and older identified cataract and macular degeneration as the main causes of low vision and blindness ${ }^{47}$. Diabetic retinopathy has been estimated to be the most common cause of blindness among working-age Australians ${ }^{48}$. A survey designed to estimate the prevalence and causes of blindness in the Kingdom of Tonga, showed that the prevalence of blindness in the Kingdom was $0.47 \%$. All that were affected were aged over 50 years and cataract was responsible for $68.4 \%$ of blindness and low vision (83\%) among population over 20 years of age ${ }^{49}$.

A summary of the causes of low vision and blindness in the various regions of the world is shown in Table 1.

\section{Childhood low vision and blindness}

A large proportion of low vision and blind children live in the developing countries. An estimated 1.5 million children are blind worldwide and most of them live in $\mathrm{Asia}^{50}$. The causes and prevalence 
of low vision and blindness vary significantly from one region to another, being influenced by factors such as socioeconomic factors in the region. In the developed countries, the prevalence of blindness is in the range of $0.02-0.04 \%$, whereas, in developing countries, the prevalence can be as high as 0.11 percent $^{51}$. Causes of blindness in children are commonly genetic in origin. These include congenital cataract, congenital nystagmus, Leber's amaurosis, retinitis pigmentosa, Usher's syndrome, albinism, congenital glaucoma, microphthalmos, anophthalmos, aniridia et cetera. A review of data on childhood low vision and blindness are presented below.

\section{Africa}

There is a large number of partially sighted and blind children in Africa and the causes of the conditions differ from what one would find in the adult or general population. Data from Malawi, Gambia, Nigeria, Benin, and Cameroon have shown that childhood blindness prevalence in these parts of Africa ranges from 0.5 to 1.10 per 1000 children $^{52-}$ 56. Childhood visual impairment from these parts of East and West Africa has been reported to be mainly due to measles, small pox, malnutrition and congenital cataract ${ }^{52-56}$. The major causes of childhood blindness in South Africa ${ }^{20}$ have been reported to be nutritional (vitamin A deficiency), infections (measles, rubella, ophthalmia neonatorum), inherited genetic disorders. Others include problems related to birth, harmful eye practices by non trained workers and cerebral hypoxia. The most common genetic eye disorders reported were retinitis pigmentosa, albinism, cataract and glaucoma, while problems related to birth were mainly retinopathy of prematurity ${ }^{20}$. In a national survey ${ }^{57}$ of children at 15 schools for the blind in South Africa, hereditary diseases accounted for 33\% of low vision and blindness. Others were intrauterine factors such as rubella and toxoplasmosis $(0.9 \%)$ and perinatal conditions such as retinopathy of prematurity and ophthalmic neonatorum (13.1\%). Following a study of the record cards of children attending special education schools in the Northern Province of South Africa, it was found that albinism was the common cause of low vision among the children ${ }^{58}$.

\section{Americas and Canada}

A study ${ }^{59}$ in Metropolitan Atlanta, USA, identified genetic condition (43\%) as a major cause of visual impairment among children. Similar findings were reported in a study at Alabama, by Decarlo and Nowakowski ${ }^{60}$ who found visual impairment $(30.9 \%)$ resulting mainly from optic

Table 1. Causes of low vision and blindness in different parts of the world.

\begin{tabular}{|c|c|c|c|c|}
\hline \multicolumn{5}{|c|}{ Common causes of blindness and low vision in various regions of the world } \\
\hline Africa & $\begin{array}{l}\text { America and } \\
\text { Canada }\end{array}$ & $\begin{array}{l}\text { East Med. and } \\
\text { Asia Pacific }\end{array}$ & Europe & Oceania \\
\hline $\begin{array}{l}\text { Senile cata- } \\
\text { ract, glaucoma, } \\
\text { corneal opacity } \\
\text { (non-trachoma- } \\
\text { tous), uncor- } \\
\text { rected aphakia, } \\
\text { infections and } \\
\text { diseases (oncho- } \\
\text { cerciasis, tracho- } \\
\text { matous and non- } \\
\text { trachomatous) } \\
\text { xerophthalmia, } \\
\text { trauma, macula } \\
\text { degeneration }\end{array}$ & $\begin{array}{l}\text { Diabetes, cataract, } \\
\text { age-related macu- } \\
\text { lar degeneration }\end{array}$ & $\begin{array}{l}\text { Cataract, corneal } \\
\text { opacities (non- } \\
\text { trachomatous), } \\
\text { infections (tracho- } \\
\text { matous and non- } \\
\text { trachomatous), } \\
\text { retinitis pigmen- } \\
\text { tosa, age-related } \\
\text { macular degenera- } \\
\text { tion, diabetic reti- } \\
\text { nopathy, glauco- } \\
\text { ma, optic atrophy }\end{array}$ & $\begin{array}{l}\text { Age-related } \\
\text { macular degen- } \\
\text { eration, glaucoma, } \\
\text { cataract, diabetic } \\
\text { retinopathy, } \\
\text { hereditary retinal } \\
\text { dystrophies, } \\
\text { optic atrophy }\end{array}$ & $\begin{array}{l}\text { Age-related } \\
\text { macular degen- } \\
\text { eration, dia- } \\
\text { betic retinopathy, } \\
\text { cataract }\end{array}$ \\
\hline
\end{tabular}


nerve involvement (optic atrophy, Leber's optic, optic nerve hypoplasia), primary aniridia (12.2\%), cataract/aphakia (13.8), albinism (13.0\%), and retinitis pigmentosa, to be the most common causes of childhood visual impairment. In Brazil, congenital disorders, bilateral toxoplasmic macular scar, optic atrophy and cataract have been reported as the main causes of low vision in children ${ }^{61}$. A survey of childhood blindness in Peruvian children identified congenital and hereditary conditions (leukoma, congenital cataract, congenital glaucoma, tapetoretinal degeneration, optic atrophy and retinoblastoma) as well as infections (measles) as the most common causes of blindness ${ }^{62}$. Childhood blindness in Chile ${ }^{63}$ has been attributed to hereditary factors (29.6\%), perinatal factor (22.5\%), and intra-uterine factor $(8.2 \%)$. Retinopathy of prematurity accounted for $17.6 \%$ of all children with severe visual loss in that country. A review presented by Manos and West $^{26}$ indicated that the common causes of childhood blindness in Argentina, Bolivia, Brazil and Chile were retinopathy of prematurity, glaucoma, cataract and optic atrophy.

\section{East Mediterranean and Asia Pacific region.}

A high prevalence of childhood visual impairment and blindness has been reported in many parts of Asia. In India, corneal staphyloma, corneal scar and phthisis attributed to vitamin A deficiency have been found to be major causes of childhood blindness ${ }^{64}$. Another study ${ }^{65}$ in the country found hereditary/congenital conditions such as congenital glaucoma, hereditary macular degeneration, retinitis pigmentosa and albinism) to be major causes of visual impairment accounting for $64 \%$ of cases. Hornby et $a l^{66}$ also found hereditary factors $(34.8 \%)$ as a major cause of blindness and low vision among children attending special education schools in India. In Sri Lanka ${ }^{67}$, hereditary diseases $(35 \%)$ intra-uterine factors $(3.5 \%)$ were common causes of blindness among children attending schools for the blind. The hereditary factors included bilateral microphthalmos (26\%), anophthalmos and phthisis $(10 \%)$ and retinal diseases were the second most common cause of visual loss accounting for $22 \%$ of cases. Cataract (17\%) was reported as the main cause of 'avoidable' childhood low vision. Other causes of low vision and blindness in
Sri Lanka were optic nerve atrophy (7\%), congenital glaucoma (6\%) and corneal scarring associated with vitamin A deficiency (2\%).

In Saudi Arabia ${ }^{28}$, the prevalence of low vision among children was $1.16 \%$ (male) and $1.22 \%$ (females) and the corresponding values for blindness were $0.24 \%$ and $0.20 \%$ respectively. In the West Bank and Gaza strip of the Middle East, toxoplasmosis, optic atrophy and glaucoma have been reported to be the main causes of blindness ${ }^{68}$. In a national epidemiological survey of blindness and low vision in China, hereditary factors (48.46\%) were found to be the leading causes of blindness among children less than 14 years of age $^{38}$. A survey of childhood blindness in China among children in the blind schools in 18 provinces found microphthalmos $(25.5 \%)$, retinal dystrophies $(24.9 \%)$, and cataract $(18.8 \%)$ to be major causes of childhood blindness ${ }^{69}$. Sight-threatening conditions affecting children in Hong Kong were generally congenital or hereditary in nature ${ }^{34}$. Also, in Malaysia ${ }^{39}$, hereditary and congenital structural defects were reported as the common causes of visual impairment among children.

\section{Europe}

Blindness registration data from England, Wales and the Scandinavian countries have been used to estimate that the prevalence of blindness in children ranges from 0.1 to 0.4 per 1000 children $^{51}$. In England, among children under 16 years of age, major causes of registered blindness were congenital anomalies. These included congenital cataract $(25 \%)$ and optic atrophy $(20.4 \%)$. Others were degenerative conditions $(7.4 \%)$, and hereditary retinal dystrophies $(6.9 \%)^{42}$. In Cyprus ${ }^{70}$, hereditary diseases $(79 \%$ of cases), pre-natal (non-genetic) 4\%, perinatal and post natal acquired conditions (13\%) were the common causes of childhood blindness. In Iceland $^{71}$ hereditary diseases have been found to be the major cause of childhood blindness. In a national survey of blindness among children in the Republic of Ireland, genetic conditions (Leber's amaurosis, albinism, cortical blindness) constitute $16 \%$, prenatal cases (optic nerve hypoplasia, optic atrophy, cortical blindness) $40 \%$ and perinatal conditions (retinopathy of prematurity, 
Table 2. Causes of Childhood low vision and blindness in different parts of the world.

\begin{tabular}{|c|c|c|c|c|}
\hline \multicolumn{5}{|c|}{ Common causes of childhood low vision and blindness in various regions of the world } \\
\hline Africa & $\begin{array}{l}\text { Americas and } \\
\text { Canada }\end{array}$ & $\begin{array}{l}\text { East Mediter- } \\
\text { ranean and Asia } \\
\text { Pacific }\end{array}$ & Europe & Oceania \\
\hline $\begin{array}{l}\text { Hereditary/Con- } \\
\text { genital } \\
\text { Cataract, glaucoma } \\
\text { albinism, microph- } \\
\text { thalmos, anophthal- } \\
\text { mos, optic atrophy, } \\
\text { uveal coloboma, } \\
\text { buphthamos. Reti- } \\
\text { nitis pigmentosa } \\
\text { Acquired includ- } \\
\text { ing infections } \\
\text { xerophthalmia, } \\
\text { trauma amblyopia, } \\
\text { infections (easles, } \\
\text { small pox, rubella) }\end{array}$ & $\begin{array}{l}\text { Hereditary/Con- } \\
\text { genital } \\
\text { Optic atrophy, } \\
\text { Leber's optic nerve } \\
\text { atrophy, aniridia, } \\
\text { cataract, albinism, } \\
\text { toxoplasmic macu- } \\
\text { lar scar, perinatal } \\
\text { factors, retinopathy } \\
\text { of prematurity }\end{array}$ & $\begin{array}{l}\text { Hereditary/Con- } \\
\text { genital } \\
\text { Cataract, glaucoma, } \\
\text { optic nerve atrophy, } \\
\text { microphthalmos, } \\
\text { anophthalmos, } \\
\text { Usher's disease, } \\
\text { Leber's maurosis. } \\
\text { nystagmus, reti- } \\
\text { nitis pigemntosa, } \\
\text { albinism, macular } \\
\text { degeneration } \\
\text { Acquired includ- } \\
\text { ing infections } \\
\text { Trachoma, xeroph- } \\
\text { thalmia, toxoplas- } \\
\text { mosis }\end{array}$ & $\begin{array}{l}\text { Hereditary/Con- } \\
\text { genital } \\
\text { Congenital cata- } \\
\text { ract, nystagmus, } \\
\text { Leber's amau- } \\
\text { rosis, retinitis } \\
\text { pigmentosa, } \\
\text { Ushers syndrome } \\
\text { albinism, optic } \\
\text { atrophy, optic } \\
\text { nerve hypoplasia }\end{array}$ & $\begin{array}{l}\text { Hereditary/Con- } \\
\text { genital } \\
\text { Cataract, nys- } \\
\text { tagmus, rubella, } \\
\text { albinism, optic } \\
\text { atrophy, aniridia, } \\
\text { microphthalmos. } \\
\text { Leber's amaurosis. } \\
\text { macular dystro- } \\
\text { phy (including } \\
\text { Stargardt's). } \\
\text { Acquired } \\
\text { trauma }\end{array}$ \\
\hline
\end{tabular}

optic atrophy and cortical blindness) $27 \%$ constitute the major causes of blindness ${ }^{72}$.

\section{Oceania}

In Australia, hereditary diseases were the main causes of blindness in children ${ }^{73,74}$. Data collected from a low vision clinic at Brisbane showed that primary congenital nystagmus $(17.6 \%)$ was the most common cause of low vision among children. Other common causes were congenital cataract $(15.8 \%)$, rubella $(9.3 \%)$, albinism $(7.5 \%)$, and primary optic atrophy $(6.3 \%)^{73}$. A retrospective study of pediatric clinical files from the Kooyong low vision clinic (Melbourne, Australia) ${ }^{74}$ showed that the major causes of low vision were congenital or inherited conditions. These included congenital cataract $(13.5 \%)$, primary optic atrophy $(9.4 \%)$, macular dystrophies (Stargardt's and other dystrophies) (8.3\%), congenital nystagmus $(7.8 \%)$, albinism (7.6\%), and rubella (5.9\%).

The above review shows that congenital, intra-uterine and perinatal conditions are the common causes of childhood blindness worldwide. A summary of the various causes of low vision and blindness in the various regions of the world is shown in Table 2.

\section{Consequences of low vision and blindness}

Ocular disorders resulting from genetic or disease conditions may lead to visual impairment and visual disability, which may subsequently lead to visual handicap. Visual handicap has been defined as the actual or perceived social, economic and psychological disadvantages which result from visual disability $^{75}$. All blind and many low vision patients face problems in performing visually guided daily activities such as reading, identifying street names, house numbers, object recognition, mobility, driving, chopping foods, measuring liquids, watching television et cetera. The limitations and frustrations experienced by these people can result in loss of independence, depression and in many cases, a deterioration of general health ${ }^{76}$. Low vision and blindness are more common among the elderly who in addition may have difficulty in hearing, 
may have systemic problems such as diabetes or hypertension. The vision problem, therefore complicates the health problems, hence, presents a greater risk for depression and other emotional manifestations.

Many visually impaired persons are economically disadvantaged because of their visual status. Many cannot find a job or could lose their jobs due to visual loss. Also, the social attention required by this category of people is great. Many blind people need other people to take care of them, this may in certain cases, require full time care, hence, preventing others from taking up employments. Blindness (childhood or adult) is of major economic and social consequence to the family, the community and the nation. It is usually more costly to educate partially sighted and blind persons than their normally sighted counterparts. Also, rehabilitation of the visually impaired person is quite expensive, relying on interdisciplinary professionals or paraprofessionals to provide effective services. Eye care is just a component of the need of the visually impaired persons; hence eye care professionals do not have the total responsibility for the rehabilitation of the visually impaired. Quite often, the patient requires other services (social, psychological, educational, economic et cetera, which cannot be met by the eye care professionals. This makes rehabilitation of the visually impaired persons quite complicated and expensive.

Sudden visual loss can lead to feelings of shock, denial and anger which may eventually lead to depression. Slow but progressive vision loss can lead to anxiety, apprehension and worry about becoming blind and consequences of blindness. These psychological manifestations are quite expected, especially if a person becomes suddenly blind or faces imminent blindness as an adult. As others must go to work or to school, the visually impaired person may have to stay at home. This may lead to feelings of social isolation, unhappiness, low self esteem and hopelessness. Visual impairment can be debilitating and devastating, particularly so if it occurs during adulthood. This person has been independent in all spheres of life, but suddenly has to rely on others for even mundane activities such as reading letters, walking around, cooking and self keeping. In view of these socio-economic and psychological implications of low vision and blindness, this category of people needs multidisciplinary approach for their comprehensive rehabilitation and require special needs which should be given due attention by health, academic and social institutions.

\section{Conclusion}

Cataract constitutes a major cause of blindness and low vision among adults and elderly in many parts of the world, while genetic and perinatal conditions were the most common cause of childhood blindness. It is difficult to compare the prevalence data for low vision and blindness in different parts of the world because of the differences in ages of the subjects and methods of the data collection employed. In general, however, the conditions are more prevalent in the developing countries than in the developed ones, therefore requiring greater attention by the health care authorities. Appropriate and effective preventive strategies in form of eye care education may greatly reduce the high prevalence of visual impairment due to infections and malnutrition in the developing countries. Also, greater focus on cataract surgery will reduce blindness due to cataract world wide.

\section{References}

1. Thylefors B, Negrel AD, Pararajasegaram R, Dadzie, KY. Global data on blindness. Bull World Health Organ 199573 115-121.

2. Thylefors B, Negrel AD, Pararajasegaram R, Dadzie, KY. Global data on blindness. Community Eye Health 19969 1-8.

3. Watkins RD. The management of global blindness. Clin Exp Optom 200184 104112.

4. Lewallen S, Courtright P. Blindness in Africa. Present situation and future needs. Br J Ophthalmol 200185 897-903.

5. Thylefors B. A global initiative for elimination of avoidable blindness. Am J Ophthalmol 1998125 90-93.

6. Pararajasegaram R. Vision 2020 - the right to sight: From strategies to action. Am J Ophthalmol 1999128 359-360. 
7. Chatterjee S. Blindness in Ghana and its rehabilitation. Ghana Med J 1970 314-315.

8. Moll AC, van der Linden AJ, Hogeweg M, Schader WE, Hermans J, de Keizer RJ. Prevalence of blindness and low vision of people over 30 years in the Wenchi district, Ghana in relation to eye care programmes. Br J Ophthalmol 199478 275-278.

9. Wilson MR,Mansour M, Ross-Degnan D, Moukouri E, Alemayehu W, Martone JF, Casey R, Bazargan M. Prevalence and causes of low vision and blindness in the extreme North Province of Cameroon, west Africa. Ophthal Epidemiol 19963 23-33.

10. Adeoye A. Survey of blindness in the rural communities of South West Nigeria. Trop Med Int Health 19961 672-676.

11. Ezepue UF. Magnitude and causes of blindness in Anambra state of Nigeria. Pub Health 1997111 305-309.

12. Kortlang C, Koster JC, Coulibaly S, Dubbeldam RP. Prevalence of blindness and visual impairment in the region of Segou, Mali. A baseline survey for a primary health care programme. Trop Med Int Health 1996 $1314-319$.

13. Potter AR. Causes of blindness and visual handicap in the Central African Republic. Br J Ophthalmol 199175 326-328.

14. Whitfield R, Schwab L, Ross-Degnan D, Steinkuller P, Swartwood J. Blindness and eye disease in Kenya: Ocular status survey results from Kenya rural blindness prevention project. Br J Ophthalmol 199074 333-340.

15. Loewenthal R, Pe'er J. A prevalence survey of ophthalmic diseases among the Turkana tribe in North West-Kenya. Br J Ophthalmol 199074 84-88.

16. Courtright $\mathrm{P}$, Klungsoyr $\mathrm{P}$, Lewallen $\mathrm{S}$, Henriksen TH. The epidemiology of blindness and visual loss in Hamar tribesmen of Ethiopia. Trop Geogr Med 199345 168-170.

17. Zerihun N, Mabey D. Blindness and low vision in Jimma Zone, Ethiopia: result of a population based survey. Ophthal Epidemiol 19974 19-26.

18. Cook CD, Knight SE, Croften-Briggs I.
Prevalence and causes of low vision in Kwazulu Natal. South Afr Med J 199383 590-593.

19. Bucher PJM, Ijsselmuiden. Pevalence and causes of blindness in the Northern Transvaal of South Africa. Br J Ophthalmol 198872 721-726.

20. Pougnet VN. Report of the Working Group to the National Eye Care Committee on an eye care program for South Africa. 1995.

21. Oduntan, Nthangeni, Ramudzuli and Madu. Causes and prevalence of low vision and blindness in black South African adults in the Limpopo Province. S Afr Optom 2002 62 8-15.

22. Newland HS, White AT, Greene BM, Murphy RP, Taylor HR. Ocular manifestation of onchocerciasis in a rain forest area of West Africa. Br J Ophthalmol 199175 163-169.

23. Tielsch JM, Somer A, Witt K, Katz J, Royal RM. Blindness in American urban population. Arch Ophthalmol 1990108 286-290.

24. Sommer A, Tielsch JM, Katz J, Quigley HA, Gottsch JD, Javitt JC, Martone JF, Royal RM, Witt KA, and Ezrine S. Racial differences in the cause-specific prevalence of blindness in East Baltimore. N Eng J Med 1991325 1412-1417.

25. Munoz B, West SK, Rubin GS, Schein OD, Quigley HA, Bressler SB, Bandeen-Roche $\mathrm{K}$. Causes of blindness and visual impairment in a population of older Americans. The Salisbury eye study. Arch Ophthalmol 2000118 819-825.

26. Munoz B and West SK. Blindness and visual impairment in Americas and Caribbean. Br J Ophthalmol 200286 498-504.

27. Canadian National Institute for the blind (CNIB). Statistical information for the client population of the CNIB. Toronto, 1989.

28. Angra SK, Murhy GV, Gupta SK, Angra V. Cataract-related blindness in India and its social implications. India Med Res 1997 106 312-324.

29. Minassian DC, Vehra V. 3.8 million blinded by cataract each year: projections from the 
first epidemiological study of incidence of cataract blindness in India. Br J Ophthalmol 199074 341-343.

30. Tabbara KF, Ross-Degnan D. Blindness in Saudi Arabia. J Am Med Assoc 1986255 3378-3405.

31. Bourne RA, Dineen B, Modasser MA, Mohammed MN, Johnson GJ. The national blindness and low vision prevalence survey of Bangladesh: Research design, eye examination methodology and result of pilot study. Ophthal Epidemiol 20029 119-132.

32. Baasanhu J, Johnson GJ, Burendei G, Minassian DC. Prevalence and causes of visual impairment in Mongolia: a survey of population 40 years and older. Bull World Health Organ 199472 771-776.

33. Mansour AM, Kassak K, Chaya M. National survey of blindness and low vision in Lebanon. Br J Ophthalmol 199781 905906.

34. Fatouhi, A, Hashemi H, Mohammad K and Jalali KH. The prevalence and causes of visual impairment in Tehran. The Tehran Eye study, Iran. Br J Ophthalmol $2004 \mathbf{8 8}$ 740-745.

35. Pokhrel GP, Regni G, Shstha SK, Negrel AD, Ellwein LB. Prevalence of blindness and cataract surgery in Nepal. Br J Ophthalmol 199882 600-605.

36. Yap M, Cho J, Woo G. A survey of low vision patients in Hong Kong. Clin Exp Optom 199073 19-22.

37. Michon JJ, Lau J, Chan WS, Ellwein. Prevalence of visual impairment, blindness and cataract surgery in the Hong Kong elderly. Br J Ophthalmol 200286 133-139.

38. Zhang SY, Zou LH, Gao YQ, Di Y, Wang XD. National epidemiological survey of blindness and low vision in China. Chinese Med J 1992105 603-608.

39. Mohidin N, Yusoff S. Profile of a low vision clinic population. Clin Exp Optom 199881 198-202.

40. Negrel AD, Minassian DC, Sayek F. Blindness and low vision in South East Turkey. Ophthal Epidemiol 19963127134.
41. Giltrow-Tyler JF. Causes of blindness and partial sight among adults in 1976/77 and 1980/81. (England. HMSO June 1988). Optician 1988.

42. Yap M, Weatherill, J Causes of blindness and partial sight in the Bradford metropolitan district from 1980-1985. Ophthal Physiol Opt 19899 289-292.

43. Munier A, Gunning T, Kenny D, O'Keefe M. Causes of blindness in adult population of the Republic of Ireland. $\mathrm{Br} J$ Ophthalmol 199882 630-633.

44. Rosenberg T, Klie F. The incidence of registered blindness caused by age-related macular degeneration. Acta Ophthalmol Scand 199674 399-402.

45. Ponte F, Guiffre G. Prevalence and causes of blindness and low vision in the Castledaccia Eye Study. Vision Res 199535 S57.

46. Van Newkerk MR, Weih L, McCarty CA, Stanislavsky YL, Keeffe JE, Taylor HR. Visual impairment and eye diseases in elderly institutionalized Australians. Ophthalmol 2000107 2203-2208.

47. Attebo K, Mitchell P, Smith W. Visual acuity and the causes of visual loss in Australia. The Blue Mountain Eye Study. Ophthalmol. 1966103 357-364.

48. O' Shea JG. Screening for diabetic retinopathy, the leading cause of blindness among Australian working age. Clin Exp Optom 199881 21-28.

49. Newland HS, Woodward AJ, Taumoepeau LA. Epidemiology of blindness and visual impairment in the Kingdom of Tonga. $\mathrm{Br} J$ Ophthalmol 199478 344-348.

50. Foster A, Gilbert CE. Epidemiology of childhood blindness. Eye 19926 173- 176.

51. Gilbert CE, Anderton L, Dandona L, Foster A. Prevalence of visual impairment in children: A review of available data. Ophthal Epidemiol 19996 73-82.

52. Merin S. Malnutrition as a cause of blindness in children. Malawi Med Bull 19672 6-10.

53. Olurin O. Etiology of blindness in Nigeria. Am J Ophthalmol 197070 533- 540. 
54. Ben-Ezra D, Chirambo MC. Childhood blindness in a developing country. Metab Ophthalmol 19782 103-105.

55. Gilbert CE, Wood M, Waddel K, Foster A. Causes of childhood blindness in East Africa. Ophthal Epidemiol 19952 77-84.

56. Waddel KM. Childhood blindness and low vision in Uganda. Eye 199812 184-192.

57. O' Sullivan J, Gikbert C, Foster A. The causes of childhood blindness in South Africa. S Afr Med J 199787 1691-1695.

58. Oduntan AO. Causes of low vision and blindness in Black South African children attending special education schools in the Northern Province of South Africa. $S$ Afr Optom 200160 120-123.

59. Mervis CA, Yeargin-Allsopp M, Winter S, Boyle C. Aetiology of childhood vision impairment, metropolitan Atlanta, 19911993. Paediatr Perinat Epidemiol 200014 70-77.

60. De Carlo DK, Nowakowski R. Causes of visual impairment among students at the Alabama school for the blind. $J$ Am Optom Assoc 199970 647-652.

61. de Carvalho KM, Minguini N, Moreira Filho DC, Kara-Jose N. Characteristics of a pediatric low vision population. $J$ Pediatr Ophthalmol Strab 199835 162-165.

62. Rojas JR, Lavado L, Echegaray L. Childhood blindness in Peru. Ann Ophthalmol 199022 423-425.

63. Gilbet CE, Canovas R, Foster A. Causes of blindness and severe visual impairment in children in Chile. Dev Med Child Neurol 199436 326-333.

64. Rahi JS, Sripath S, Gilbert CE and Foster A. Childhood blindness in India: Causes in 1318 blind school children in 9 states. Eye 19959 945- 550.

65. Gothwal VK, Herse P. Characteristics of paediatric low vision population in a private eye hospital in India. Ophthal Physiol Opt 200020 212-219.

66. Hornby SJ, Adolph S, Gothwal VK, Gilbert CE, Dandona L, Foster A. Evaluation of children in six blind schools of Andhra Pradesh.
Indian J Ophthalmol 200048 195-200.

67. Ecktein MB, Foster A, Gilbert CE, Foster A. Causes of childhood blindness in SriLanka: result from children attending six schools for the blind. Br J Ophthalmol 1995 79 633-636.

68. Elder MJ, de Cock R. Childhood blindness in the West Bank and Gaza Strip: Prevalence, etiology and hereditary factors. Eye 19937 580- 583.

69. Hornby SJ, Xiao Y, Gilbert CE, Foster A, Wang X, Liang X, Jing H, Wang L, Min W, Shi Y, Li Y. Causes of childhood blindness in People's Republic of China: results from 1131 blind school students in 18 provinces. Br J Ophthalmol 199983 929-932.

70. Merin S.LapithisAG.HororitzD, Michaelson IC. Childhood blindness in Cyprus. Am J. Ophthalmol 197274538542.

71. Halldorsson S. Bjornsson G. Childhood blindness in Iceland: A study of legally blind and partially seeing children in Iceland. Acta Ophthalmol 198055 237- 342.

72. Goggin FM, O' Keefe M. Childhood blindness in the Republic of Ireland: A national survey. Br J Ophthalmol 199175 425- 429.

73. Lovie-Kitchin JE, Bevan JD. Paediatric low vision - a survey. Aust J Optom $1982 \mathbf{6 5}$ 169-177.

74. Kalloniatis M, Johnston AW. Visual characteristics of low vision children. Optom Vis Sci 199067 38-48.

75. Leat SJ, Legge GE and Bullimore. A redefinition of definitions. Optom Vis Sci 199976 198-221.

76. Gillman AE, Simmen A, Simon EP. Visual handicap in the aged: self reported visual disability and the quality of life of residents of public housing for the elderly. $J$ Vis Imp Blind 198680 588-590. 